\title{
POLYMORPHIC SITE INDEX CURVES FOR BEECH (FAGUS SYLVATICA L.) IN CENTRAL AND EASTERN SERBIA
}

\author{
POLIMORFNE KRIVULJE INDEKSA STANIŠTA EUROPSKE BUKVE \\ (Fagus sylvatica L.) U CENTRALNOJ I ISTOČNOJ SRBIJI
}

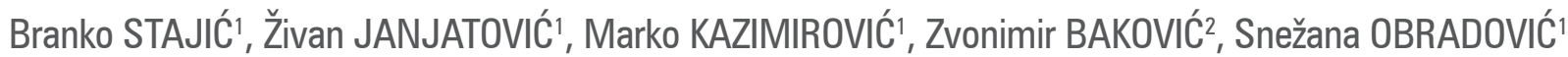

\begin{abstract}
SUMMARY
This study was mainly aimed at constructing polymorphic site index curves for beech in the central (Rudnik mountain - RU, about 15,000 ha) and eastern (Žagubica - ŽA, about 7,000 ha) part of its distribution in Serbia. To obtain suitable height-age data and evaluate the best-fit growth model we used 107 felled dominant beech trees. The Korf, Korsun and Chapman-Richards growth functions per site class were first parameterized and then mutually compared with respect to residual statistics and the significance of their parameters. They were additionally parameterized in line with empirical data on the value and age of the culmination of current annual height increment $\left(\mathrm{CAI}_{\mathrm{h}}\right)$. The obtained results indicated that the Chapman-Richards growth function showed the best results both by statistical (residuals standard error, significance of the parameters, distribution of residuals, and homoscedasticity) and by empirical criteria (the $\mathrm{CAI}_{\mathrm{h}}$ culmination time, the maximal values of the $\mathrm{CAI}_{\mathrm{h}}$, and the attained height of trees at a certain age) of the height-age beech modelling in the analyzed regions. The obtained polymorphic site index curves which classify sites with regard to their productivity can be very helpful in planning appropriate silvicultural treatments, and for decision-making in forest management planning, forest policy and ecology and, consequently, in the sustainable management of beech forests in Serbia and some neighbouring countries with a similar forestry sector development.
\end{abstract}

KEY WORDS: height growth pattern, site index curves, beech, Serbia.

\section{INTRODUCTION}

UVOD

As a major driver of forest resource availability, forest productivity remains a fundamental concern in forestry (Bontemps and Bouriaud 2014). From this reason, efficient silviculture, yield and growth forecasting, forest management planning and decision-making on different levels require a reliable measure of site productivity (Wanclay and Henry 1988, Palahí et al. 2004, Pretzsch 2009 etc.). The most important indicator of potential forest site productivity is the dominant height of a stand at a reference age - the site index (Monserud 1984, Skovsgaard and Vanclay 2008, Zlatanov et al. 2012, Stajić et al. 2016 etc.). This is due fact that the height (and age) of dominant trees correlates closely with the total stand volume production and is less dependent on the stand density and thinning intensity (Davis and Johnson 1987, Stamenković and Vučković 1988, Pretzsch 2009 etc.).

Determination of site index model parameters and site productivity assessment largely depends on the quality of avail-

1 Dr. Branko Stajić, MSc Živan Janjatovića, MSc Marko Kazimirović, Dr. Snežana Obradović, University of Belgrade, Faculty of Forestry, Kneza Višeslava 1, 11030 Belgrade, Serbia

${ }^{2}$ Dr. Zvonimir Baković, Public Enterprise Srbijašume, Bulevar Mihajla Pupina 113, 11000 Belgrade, Serbia

Corresponding author: branko.stajic@sfb.bg.ac.rs 
able data. In fact, three distinct sources of height-age data for site index curves constructions have been widely used in literature (Clutter et al. 1983): temporary sample plots, stem analyses data, and permanent sample plots. The data on the height of trees at different ages (temporary sample plots) is the least usable. It does not provide completely valid information on the real height growth of individual stands, but in the absence of other data, it is still often used (Nanang and Nunifu 1999). Nonetheless, height observations (and sometimes age) are subject to the sampling and measurement error (García 2011) and the so-called "age trend" (Socha et al. 2016), which can cause a bias in the data from temporary sample plots. Another shortage of this data is the need to make the assumption that all sites are equally sampled at all ages (Monserud 1984). This type of heightage data was used to construct the existing anamorphic site index curves for beech in Serbia (Stajić et al. 2016). In the procedure of their construction, asymptote coefficients of growth curve models are only changed resulting in site index curves with the same shape, causing the main drawback of anamorphic site index curves - the same age of the current height increment culmination. This assumption cannot be considered biologically totally justified and it is wellknown that the better the site is, the earlier the current height increment culminates in even-aged stands and the greater the increment value at the moment of culmination is (Sloboda 1971, Kramer 1988, Vučković 1989, Stajić 2010). To account for differences in the height growth pattern per site, the dominant height growth is commonly modelled by polymorphic site index functions (Mamo, Sterba 2006).

In spite of the relevance of site productivity estimations for forest management, studies on site productivity assessment regarding site index curves have not been carried out very intensively, both in Serbia and in the entire Region of former Yugoslavia. In majority countries, a classification of site productivity in has been conducted either by applying the mean height-diameter relations or the mean height-age relations (see Stajić et al. 2016). In order to improve the existing system of site classification according to productivity, to harmonize it with the dominant mode of site productivity estimation in Europe and to create opportunities for the comparison of the obtained results in Serbia with the results of site index investigations from other countries, it is necessary to establish site index curves for the main tree species. It is especially important for European beech (Fagus sylvatica L.), which represents the most important and one of the most productive tree species in Serbia (Vučković and Stajić 2005). Its productivity largely depends on the silviculture method employed in its forests. Generally, for highquality beech wood production forestry practices and especially thinings have a special importance (Usta et al. 2019). In addition, the distance between the trees and their optimal number, and consequently the optimal size of tree growth space are also of importance for the achievement of the optimal site and stand productivity in beech forests (Lukić 1988, Vučković and Stajić 2003, Zelić 2005). Nevertheless, the wide vertical and horizontal distribution of beech on different bedrocks and in various soil evolution stages has caused large differences in the productivity of beech forests (Vučković and Stajić 2005). Previous studies of pure and mixed stands of beech don't provide enough data for a complete overview and classification of sites and stands according to the actual and potential level of production (Stajić et al. 2016). Accordingly, aim of this study was (1) modelling the beech dominant height-age relationships, (2) constructing polymorphic site index curves for beech in the central and eastern areas of its distribution in Serbia and (3) making some comparisons with beech height-age data from surrounding countries.

\section{MATERIAL AND METHODS MATERIJAL I METODE}

The research was conducted in beech stands in the Žagubica - ŽA, eastern Serbia (latitude: $44^{\circ} 10^{\prime} 3^{\prime \prime} \mathrm{N}$, longitude: $21^{\circ} 51^{\prime} 43^{\prime \prime}$ E) and Rudnik mountain - RU, central Serbia (latitude: $44^{\circ} 8^{\prime} 25^{\prime \prime} \mathrm{N}$, longitude: $20^{\circ} 29^{\prime} 33^{\prime \prime} \mathrm{E}$ ) regions, with about 15,000 ha and 7,000 ha of total forest area, respectively. The stands belong to the complex of a montane beech forest. The altitude ranges from 650 to $1,250 \mathrm{~m}(\check{Z} \mathrm{~A})$ and from 690 to $1,080 \mathrm{~m}$ (RU). The parent rock of the management unit consists of limestone and amphibolic and clay shales. Soil types include shallow, medium and deep soils on different limestone and brown acid soils. The average annual temperatures for $\breve{Z} \mathrm{~A}$ and $\mathrm{RU}$ are $9.8^{\circ} \mathrm{C}$ and $7.7^{\circ} \mathrm{C}$, respectively. The annual precipitation for $\check{Z} \mathrm{~A}$ and $\mathrm{RU}$ are of $682 \mathrm{~mm}$ and $742 \mathrm{~mm}$, respectively

A set of 62 (ŽA) and 64 (RU) dominant beech trees were used to obtain suitable height-age data. Trees were selected to cover a wide range of ages and site conditions throughout the analyzed beech forest complexes. In fact, we were selectively looking for stands or parts of stands of different age and with different site conditions over the regions, in which we felled the tallest trees. In order to get a deeper insight into the height increment relationships as precisely as possible, especially in youth, each tree was felled and crosssectioned at every $1 \mathrm{~m}$ in the first $10 \mathrm{~m}$ of the trunk and, thereafter, at $2 \mathrm{~m}$ intervals up to the terminal peak of a tree. To estimate the height from the stem analysis data, using Carmean's procedure (Newberry 1991), annual rings on each disc were precisely measured and counted.

The first step in producing polymorphic fixed base-age site index curves was to develop a guide curve fitting tree height data depending on age. According to the fitted height values at the age of 100 from the guide curves obtained $(\approx 25 \mathrm{~m})$ and the calculated standard deviations of heights at the age 
Table 1. Statistics of the sampled dominant beech trees (Min, Max, Mean and SD represent minimal, maximal, mean and standard deviation of the trees height, respectively)

Tablica 1. Statističke značajke uzorkovanih dominantnih bukovih stabala (Min, Max, Mean and SD predstavljaju minimalnu, maksimalnu, prosječnu i standardnu devijaciju visine stabala)

\begin{tabular}{|c|c|c|c|c|c|c|c|c|c|c|}
\hline \multirow{3}{*}{$\begin{array}{l}\text { Height-age classes (site classes) } \\
\text { Klasa visina-starost (klasa staništa)* }\end{array}$} & \multicolumn{2}{|c|}{$\begin{array}{c}\text { Number of trees } \\
\text { Broj stabala }\end{array}$} & \multicolumn{8}{|c|}{$\begin{array}{l}\text { Height of the sampled trees } \\
\text { Visina uzorkovanih stabala }\end{array}$} \\
\hline & \multirow{2}{*}{ ŽA } & \multirow{2}{*}{$\mathrm{RU}$} & \multicolumn{4}{|c|}{ ŽA } & \multicolumn{4}{|c|}{ RU } \\
\hline & & & Min & Max & Mean & SD & Min & Max & Mean & SD \\
\hline Class 1 (>30-34 m) & 10 & 11 & 30.2 & 33.9 & 31.7 & 1.0 & 30.1 & 32.9 & 31.3 & 1.0 \\
\hline Class 2 (>26-30 m) & 11 & 10 & 26.1 & 29.2 & 27.4 & 1.1 & 26.3 & 28.6 & 27.5 & 0.8 \\
\hline Class 3 (>22-26 m) & 12 & 12 & 23.2 & 26 & 24.8 & 1.1 & 22.2 & 25.9 & 24.3 & 1.0 \\
\hline Class 4 (>18-22 m) & 10 & 11 & 18.9 & 21.6 & 20.5 & 1.2 & 18.1 & 22 & 20.6 & 1.6 \\
\hline Class $5(<18 \mathrm{~m})$ & 10 & 10 & 14.0 & 18.0 & 15.9 & 1.6 & 14.1 & 17.7 & 15.9 & 1.5 \\
\hline Total & 53 & 54 & 14.0 & 33.9 & 25.0 & 5.1 & 14.1 & 32.9 & 25.2 & 4.6 \\
\hline
\end{tabular}

of 100 (5.1 m - ŽA and $4.6 \mathrm{~m}-\mathrm{RU})$, the dominant heightage data at the age of 100 of both regions was classified into 5 groups (site classes) of a $4 \mathrm{~m}$ "width" for each region separately (Table 1). The main statistical characteristics of the felled beech dominant trees used for site index curve modelling per determined site class are presented in Table 1.

Three well-known growth functions, the Korf, the Korsun and the Chapman-Richards (CHR) were used to establish polymorphic site growth curves. The tested functions were parameterized (Gauss-Newton procedure) for tree groups of each site class (SC) and the parameters $a, b$ and $c$ were calculated. During the parameterization procedure, the starting values of the growth function were set to initial values which satisfy the S-shape criteria with an asymptote corresponding to the site class (the more productive the site, the higher the value of the parameter $a$ ). In the case of the Chapman-Richards model, the initial value of the asymptote for the I site class was set to $40 \mathrm{~m}$, while the $b$ and $c$ parameters were set to 0.015 and 2 , respectively. Using these non-linear regressions we determined the dominant heights at the age of $100\left(\mathrm{H}_{100}\right)$ for each group of trees per site class.

According to the parameter prediction method, which relates parameter estimates to site classes, the growth model parameters $b$ and $c$ of each site class curve were set in relationship to the height at the age of $100\left(\mathrm{H}_{100}\right)$ and the parameters $b_{\mathrm{SI}}$ and $\mathrm{c}_{\mathrm{SI}}$ were obtained using the equations 1,2 and 3 (Schmidt 1969, Halaj 1978, Kindermann 2004).

The Korf function:

$$
\ln \left(b_{S I}\right)=\ln \left(b_{0}\right)+\frac{b_{1}}{H_{100}}, c_{S I}=c_{0}+\frac{c_{1}}{H_{100}}
$$

The Korsun function:

$$
\begin{aligned}
& b_{S I}=b_{0}+b_{1} \cdot H_{100}+b_{2} \cdot H_{100}{ }^{2}, \\
& c_{S I}=c_{0}+c_{1} \cdot H_{100}+c_{2} \cdot H_{100}{ }^{2}
\end{aligned}
$$

The Chapman-Richards function:

$$
\ln \left(b_{S I}\right)=\ln \left(b_{0}\right)+\frac{b_{1}}{H_{100}}, c_{S I}=c_{0}+\frac{c_{1}}{H_{100}}
$$

where: $b_{S I}$ and $c_{S I}$ are non-asymptotic parameters of the site class curves; $b_{0}, b_{1}, b_{2}, c_{0}, c_{1}$ and $c_{2}$ are parameters to be estimated, and $\mathrm{H}_{100}$ is the fitted value from the parameterized curve of the age of 100 for each site class.

By applying the Korsun function, the value of parameter $a_{S I}$ for each site index was calculated in the following form (for the Korsun function - eq. 4 and for the CHR function-eq. 5):

$$
\begin{gathered}
a_{S I}=S I \cdot \frac{1}{e^{b_{S I} \cdot \ln 100+c_{S I} \cdot \ln ^{2} 100}} \\
a_{S I}=S I \cdot \frac{1}{\left(1-e^{-b_{S I} \cdot 100}\right)^{c_{S I}}}
\end{gathered}
$$

where: SI is the site index value for the base age of 100 .

Construction of the site index curve for a particular site class using the Korsun, the Korf and the CHR growth functions was performed by the following equations (eq. 6, eq. 7, eq. 8), respectively:

Korsun: $H=a_{S I} \cdot e^{b_{S I} \cdot \ln t+c_{S I} \cdot \ln ^{2} t}$

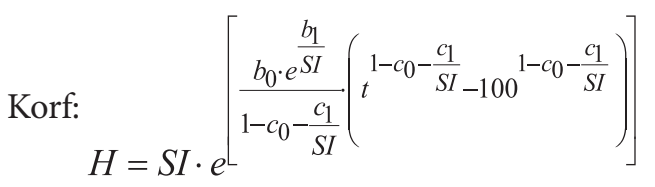

Chapman-Richards: $H=a_{S I} \cdot\left(1-e^{-b_{S I} \cdot t}\right)^{c_{S I}}$

where: $a_{S P} b_{S p}$ and $c_{S I}$ are model parameters, and $S I$ is the site index value at the age of $100\left(\mathrm{SI}_{16}, \mathrm{SI}_{20}, \mathrm{SI}_{24}, \mathrm{SI}_{28}\right.$ and $\left.\mathrm{SI}_{32}\right)$.

For the selection of a growth function to be used, various criteria have been applied. The first ones are coefficient of determination $\left(R^{2}\right)$ and residuals standard error (RSE). 

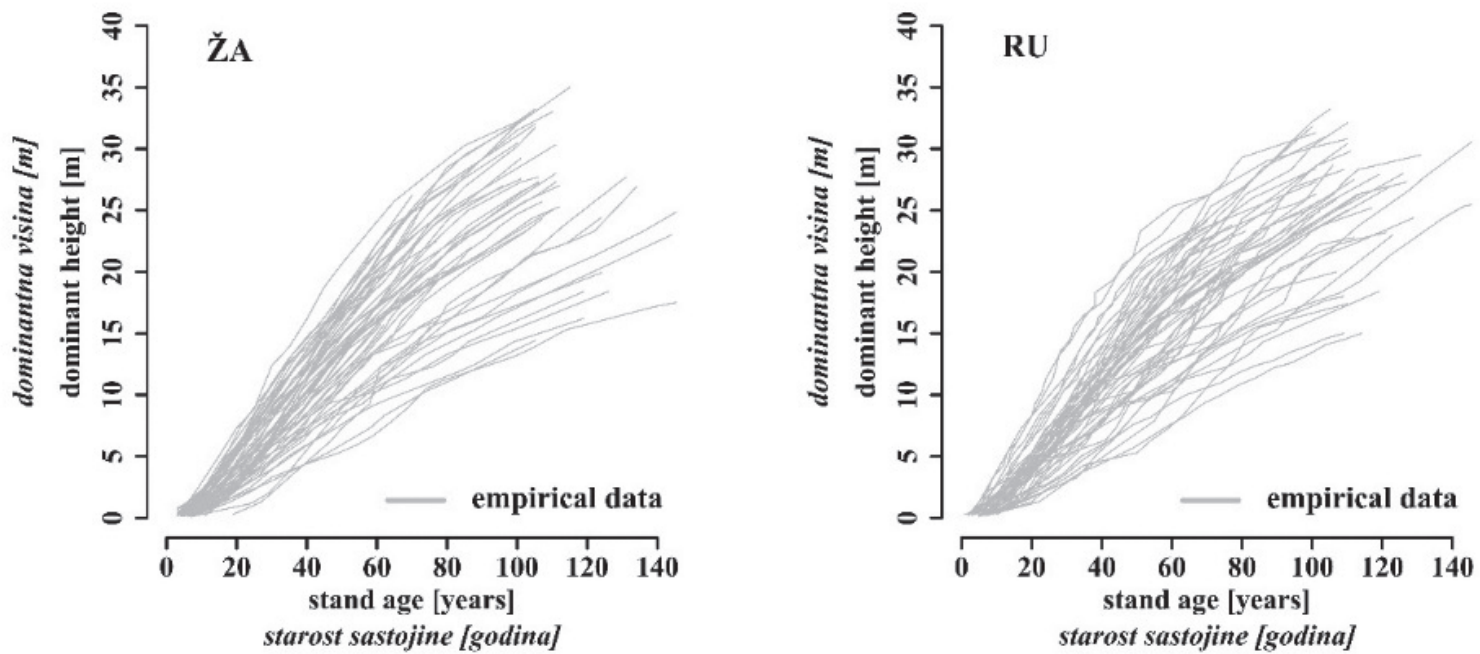

Figure 1. Height growth of the felled trees after applying Carmean's (Newberry, 1991) corrections.

Slika 1. Visinski rast primjernih stabala nakon primjene korekcija Carmeana (Newberry, 1991)

Another criterion for the selection of the best fit model was the characteristics of the residual homogeneity. In addition, the significance and predicting accuracy of the model parameters and some biological presumptions (presence of a typical S growth shape, polymorphism and asymptote) were also used to examine the best site index prediction model.

To verify the model, we used the predicted residual error sum of squares (PRESS). The procedure consisted of model fitting, refitting with one omitted observation and calculation of the predicted value of the omitted observation that was not used in the model estimation. The predicted value was calculated for each omitted observation, and PRESS statistics was calculated as follows (Eq. 9):

$$
\text { PRESS }=\sum_{i=1}^{n}\left(y_{i}-y_{i,-1}\right)^{2}
$$

where: $n$ is the number of observations, $y_{i}$ is $i_{t h}$ observation, $y_{i,-1}$ is the predicted omitted observation.

As a rule, this method is used on an independent data set. In the absence of an independent data set, the basic data set was used for model verification. This may be partially justified by the fact that the parameters of the presented model (eq.1-3) were not fitted directly but indirectly through the SI value at the age of 100 . So, in the PRESS procedure, the SI value was parameterized and with it, the whole model was reparametrized with the omitted observations (eq.1-3). The starting values of the SI variables were the observed values at the age of 100 . The calculation was performed by site classes for each tree in the site class. The values of the PRESS statistics were summarized and presented for all trees in one class. Besides the PRESS statistics, the residual sum of square (RSS) was calculated. All calculations were conducted in $\mathrm{R}$ language ( $\mathrm{R}$ core team 2008).

\section{RESULTS}

\section{REZULTATI}

The first results obtained showed that due to the existence of one or more shorter or longer periods of highly suppressed tree growth and the growth rates that deviated significantly from the expected rates (the shapes of their height growth curve were qualitatively different from the remaining trees), some felled dominant trees should be rejected. After this procedure, the definitive sample was compiled from 53 ( $\check{\mathrm{Z} A}$ ) and 54 (RU) trees to be analyzed, and their height growth per location is shown in Figure 1.

The next step in the development of polymorphic site index curves represents a parameterization of the growth functions per site class. The obtained model parameters and the statistics for the site classes are presented in Table 2.

The CHR model has the best overall features (the highest $\mathrm{R}^{2}$, parameters of all models are statistically significant), except for slightly higher values of RSE compared to the other models). The values of the asymptote parameters are highest for the Korf, followed by the Korsun and the CHR model.

The obtained statistics of the residuals of growth functions (not presented) showed that the arithmetic mean of the residuals is very close to zero, and the standard deviation of the residuals does not exceed a value greater than half the site class width of $4 \mathrm{~m}$. The values of the skewness coefficients for the CHR function are in a range between -0.207 and 0.636 , and they are the smallest compared to the values for the remaining two applied functions (from -1.234 to 0.593 , on average). The values of the kurtosis coefficients are from 2.011 to 3.423 (the CHR), from 2.017 to 5.065 (The Korsun) and from 2.037 to 5.182 (the Korf model). 
Table 2. The parameters and statistics of Korf's, Korsun's and CHR growth functions for five site classes (Significance codes: ${ }^{* * *} 0.001,{ }^{* *} 0.01,{ }^{*} 0.05$ ) Tablica 2. Parametri i statistike funkcija rasta Korfa, Korsun-a i CHR za pet klasa staništa. (Kodovi značajnosti: ${ }^{* * *} 0.001,{ }^{* *} 0.01,{ }^{*} 0.05$ )

\begin{tabular}{|c|c|c|c|c|c|}
\hline \multicolumn{6}{|c|}{ ŽA } \\
\hline \multirow[t]{2}{*}{ Model } & \multirow[t]{2}{*}{ SC } & \multicolumn{3}{|c|}{ Parameters } & \multirow[t]{2}{*}{ RSE } \\
\hline & & $\mathrm{a}$ & b & C & \\
\hline \multirow{5}{*}{ Chapman-Richards } & I & $44.303441^{* * *}$ & $0.017173^{* * *}$ & $1.620422^{* * *}$ & 1.302 \\
\hline & $\|$ & $37.855017^{* * *}$ & $0.016882^{* * *}$ & $1.457009^{* * *}$ & 1.468 \\
\hline & III & $33.713403^{* * *}$ & $0.017577^{* * *}$ & $1.745977^{* * *}$ & 1.557 \\
\hline & IV & $29.166184^{* * *}$ & $0.018702^{* * *}$ & $2.241681 * * *$ & 1.779 \\
\hline & V & $25.418282^{* * *}$ & $0.017677^{* * *}$ & $2.584143^{* * *}$ & 1.425 \\
\hline \multirow{5}{*}{ Korsun } & 1 & $0.003282^{*}$ & $3.317125^{* * *}$ & $-0.2875^{* * *}$ & 1.269 \\
\hline & ॥ & $0.002497^{* * *}$ & 3.421395 & $-0.304148^{* * *}$ & 1.426 \\
\hline & III & 0.0010249 & $3.6748129 * * *$ & $-0.3237163^{* * *}$ & 1.508 \\
\hline & IV & $0.000556^{* * *}$ & 3.8417747 & $-0.3385774^{* * *}$ & 1.737 \\
\hline & V & 0.00009028 & $4.374 * * *$ & $-0.3852^{* * *}$ & 1.382 \\
\hline \multirow{5}{*}{ Korf } & 1 & $137.36526^{* * *}$ & $7.41503^{* * *}$ & $1.50255^{* * *}$ & 1.296 \\
\hline & II & $73.6801 * * *$ & $18.5231^{* * *}$ & $1.7069 * * *$ & 1.431 \\
\hline & III & $68.7844^{* * *}$ & $21.28592^{* *}$ & $1.7181^{* * *}$ & 1.509 \\
\hline & IV & $50.172^{* * *}$ & $40.653^{*}$ & $1.851 * * *$ & 1.736 \\
\hline & V & $29.79094^{* * *}$ & $93.03773^{* *}$ & $2.0391 * * *$ & 1.343 \\
\hline \multicolumn{6}{|c|}{ RU } \\
\hline \multirow{2}{*}{ Model } & \multirow{2}{*}{ SC } & \multicolumn{3}{|c|}{ Parameters } & \multirow{2}{*}{ RSE } \\
\hline & & $\mathrm{a}$ & $\mathrm{b}$ & $\mathrm{C}$ & \\
\hline \multirow{6}{*}{ Chapman-Richards } & I & $45.597709 * * *$ & $0.015392^{* * *}$ & $1.458412^{* * *}$ & 2.061 \\
\hline & $\|$ & $37.911205^{* * *}$ & $0.015214^{* * *}$ & $1.278918^{* * *}$ & 1.787 \\
\hline & III & $35.060807^{* * *}$ & $0.015655^{* * *}$ & $1.540638 * * *$ & 1.435 \\
\hline & IV & $32.206492 * * *$ & $0.015963 * * *$ & $2.137368 * * *$ & 1.495 \\
\hline & V & $22.984882^{* * *}$ & $0.016905^{* * *}$ & $2.257907^{* * *}$ & 1.374 \\
\hline & I & $0.03441^{*}$ & $2.28445^{* * *}$ & $-0.17522^{* * *}$ & 1.991 \\
\hline \multirow{4}{*}{ Korsun } & $\|$ & $0.0008873^{* * *}$ & 3.8557999 & $-0.3516584^{* * *}$ & 1.733 \\
\hline & III & 0.0001173 & $4.556^{* * *}$ & $-0.4143^{* * *}$ & 1.409 \\
\hline & IV & $0.002248^{* * *}$ & 2.939891 & $-0.212899 * * *$ & 1.493 \\
\hline & V & $1.56 \mathrm{E}-05$ & $5.056 * * *$ & $-0.4507^{* * *}$ & 1.340 \\
\hline \multirow{5}{*}{ Korf } & I & $235.99991^{*}$ & $3.54944^{* * *}$ & $1.34994 * * *$ & 1.996 \\
\hline & $\|$ & $72.75063^{* * *}$ & $14.51739 * * *$ & $1.66624^{* * *}$ & 1.724 \\
\hline & III & $65.02911^{* * *}$ & $23.21507^{* * *}$ & $1.74009 * * *$ & 1.398 \\
\hline & IV & 250.92869 & $5.92828^{*}$ & $1.38459 * * *$ & 1.531 \\
\hline & V & $56.4992^{*}$ & 21.1556 & $1.6771^{* * *}$ & 1.342 \\
\hline
\end{tabular}

Since the fitted data for each site class could produce inappropriate culmination ages and values of the maximum current height increment $\left(\mathrm{CAI}_{\mathrm{h}}\right)$ that do not correspond to the biological growth characteristics of the site classes (the more productive the site the earlier the culmination of the $\mathrm{CAI}_{\mathrm{h}}$ and the higher its value at the time of culmination), a parameter prediction procedure was conducted. This procedure involved a new fitting of the model parameters of the growth functions representing all five site classes depending on their height at the reference age. For this purpose, $b$ and $c$ parameters of the tested growth functions were related to the fitted height of the dominant trees at the age of 100 for each site class and the parameters $b_{\mathrm{SI}}$ and $\mathrm{c}_{\mathrm{SI}}$ and, consequently, parameter $\mathrm{a}_{\mathrm{SI}}$ per site class were calculated according to the aforementioned biological precondition. When balancing these coefficients, the intension was to obtain the final models in line with the empirical data on the value and age of the $\mathrm{CAI}_{\mathrm{h}}$ culmination obtained by the stem analysis procedure (Table 4) as possible.

Table 3 shows the prediction of the model parameters used for fitting the shape and the slope coefficients of growth functions per site class.

Generally speaking, the prediction of model parameters from ŽA performed better than the prediction for RU for all three functions used. It can also be seen that the slope and shape coefficients are best predicted by the CHR function for both areas. The parameters of the Korf and the Korsun models are well predicted for $\check{Z} \mathrm{~A}$, while for RU the value of the adjusted coefficient of determination is negative, which calls into question the validity of these models. 
Table 3. Prediction of model parameters for each site class $\left(b_{S I}, c_{S l}, b_{0}, b_{1}, b_{2}, c_{0}, c_{1}\right.$ and $c_{2}$ are the model parameters; $R^{2}$ is adjusted coefficient of determination; $\mathrm{R}_{\text {adj }}^{2}$ is adjusted coefficient of determination and $\mathrm{RSE}$ is residuals standard error)

Tablica 3. Predikcija parametara modela za svaku klasu staništa (bSl, cSl, b0, b1, b2, c0, c1, i c2 su parametri modela; R2 je koeficijent determinacije; Radj je podešen koeficijent determinacije, a RSE je standardna pogreška reziduala)

\begin{tabular}{|c|c|c|c|c|c|c|c|c|c|c|c|c|c|}
\hline \multicolumn{14}{|c|}{ Korf } \\
\hline & \multicolumn{2}{|c|}{$\ln \left(b_{S l}\right)$} & $\mathrm{R}^{2}$ & $\mathbf{R}_{\text {adj }}^{2}$ & RSE & \multicolumn{2}{|c|}{$\mathrm{C}_{\mathrm{si}}$} & $\mathrm{R}^{2}$ & $\mathbf{R}_{\text {adj }}^{2}$ & \multirow[t]{2}{*}{ RSE } & & & \\
\hline & $\ln \left(b_{0}\right)$ & $b_{1}$ & & & & $c_{0}$ & $c_{1}$ & & & & & & \\
\hline RU & 1.0710 & 31.8110 & 0.39 & 0.08 & 0.83 & $1.3693^{*}$ & 5.2368 & 0.25 & -0.12 & 0.19 & & & \\
\hline ŽA & 0.4661 & $59.3096 * *$ & 0.94 & 0.92 & 0.27 & $1.2195^{* *}$ & $11.4567^{*}$ & 0.91 & 0.88 & 0.06 & & & \\
\hline \multicolumn{14}{|c|}{ Korsun } \\
\hline & & $b_{\mathrm{si}}$ & & $\mathrm{R}^{2}$ & $R_{\text {adj }}^{2}$ & RSE & \multicolumn{4}{|c|}{$\mathrm{C}_{\mathrm{si}}$} & $R^{2}$ & $\mathbf{R}_{\text {adj }}^{2}$ & RSE \\
\hline & $b_{0}$ & $b_{1}$ & $\mathrm{~b}_{2}$ & & & & $\mathrm{c}_{0}$ & \multicolumn{2}{|c|}{$\mathrm{c}_{1}$} & $\mathrm{c}_{2}$ & & & \\
\hline RU & 3.88409 & 0.11582 & -0.00505 & 0.44 & -0.12 & 1.20 & -0.27541 & \multicolumn{2}{|c|}{-0.01632} & 0.00060 & 0.34 & -0.32 & 0.14 \\
\hline ŽA & $6.18058^{* *}$ & $-0.15643^{*}$ & 0.00208 & 0.99 & 0.99 & 0.04 & $-0.54630 * * *$ & \multicolumn{2}{|c|}{$0.01383^{* *}$} & $-0.00018^{*}$ & 0.99 & 0.99 & 0.002 \\
\hline \multicolumn{14}{|c|}{ Chapman-Richards } \\
\hline & \multicolumn{2}{|c|}{$\ln \left(b_{s l}\right)$} & $R^{2}$ & $R_{\text {adj }}^{2}$ & RSE & \multicolumn{2}{|c|}{$\mathrm{c}_{\mathrm{si}}$} & $\mathrm{R}^{2}$ & $R_{\text {adj }}^{2}$ & RSE & & & \\
\hline & $\ln \left(b_{0}\right)$ & $b_{1}$ & & & & $\mathrm{c}_{0}$ & $c_{1}$ & & & & & & \\
\hline RU & $-4.2633^{* *}$ & 2.6370 & 0.99 & 0.98 & 0.006 & 0.6620 & 22.9791 & 0.98 & 0.97 & 0.08 & & & \\
\hline ŽA & $-4.2608^{* *}$ & 5.9518 & 0.99 & 0.99 & 0.003 & 0.5193 & 33.0837 & 0.87 & 0.74 & 0.17 & & & \\
\hline
\end{tabular}

Taking into account the above mentioned facts, it can be noted that the prediction of the CHR model parameters proved to be the most reliable, given the positive and relatively high value of the coefficient of determination. In addition, the CHR models for both ŽA and RU have parameters $\left(b_{0}, b_{1}\right.$, $c_{0}$, and $c_{1}$ ) of the same sign, indicating the same shape of the model curves. This is also the case with the Korf function, but not with the second-order polynomials that fitted the parameters of the Korsun function $\left(b_{0}, b_{1}, b_{2}, c_{00} c_{1}\right.$, and $\left.c_{2}\right)$.

Nevertheless, the site index curves obtained by the CHR function are best fitted into the data obtained by the stem analysis procedure (table 4). The empirical data of the $\mathrm{CAI}_{\mathrm{h}}$ culmination ages per site class and regions indicated that the beech in the area of RU, on average, reached the culmination of the $\mathrm{CAI}_{\mathrm{h}}$ earlier than in the area of ŽA. For example, the culmination age of the $\mathrm{CAI}_{\mathrm{h}}$ of beech trees in the $\mathrm{RU}$ area in the first site class (22 year) took place 5 years earlier than on the territory of $\check{Z} \mathrm{~A}$ (27 year).

Table 5 show results of PRESS and RSS statistics for each $\mathrm{SC}$ in both research regions. It can be noticed that PRESS values are in all cases higher than RSS values. Differences between the mentioned statistics (PRESS vs. RSS) are higher in the region of RU in comparison to region of $\check{Z} \mathrm{~A}$, especially for the first two SCs (I, II). In generally, no model satisfies the statistics completely. However, if we observe the first two lowest values of the PRESS (gray cells in the table) for each site class (SC), we can notice that considering all site classes in both regions, the CHR model has the first two lowest values in 8 cases, and the Korsun and Korf models in 6 cases each. So, it can be concluded that, on average, the CHR model proved to be satisfactory despite the fact that in some cases it slightly underestimates or overestimates the data, especially in the first two SCs in the RU region.

\section{DISCUSSION AND CONCLUSIONS} RASPRAVA I ZAKLJUČCI

The analyzed Korf, Korsun and CHR growth functions to be used for the purpose of site index curve construction are often found to be reliable and superior to many other functions used to model height-age relationships. Generally, the CHR function has been regarded as probably the most com-

Table 4. The modelled and empirical data of the CAlh culmination ages per SI and regions (M - mean value; Sx - standard error of the mean; Min - minimal CAlh culmination age; Max - maximal CAlh culmination age and SD - standard deviation of the culmination age data. Please refer to the text for other abbreviations.

Tablica 4. Modelirani i empirijski podaci CAlh dobi kulminacije za SI i regije (M - aritmetička sredina; Sx - standardna pogreška aritmetičke sredine; Min - minimalna vrijednost dobi kulminacije CAlh; Max - maksimalna vrijednost dobi kulminacije CAlh i SD - standardna devijacija dobi kulminacije CAlh. Za ostale kratice pogledati tekst.

\begin{tabular}{|c|c|c|c|c|c|c|c|}
\hline & \multicolumn{3}{|c|}{$\begin{array}{l}\text { Models } \\
\text { Modeli } \\
\end{array}$} & \multicolumn{4}{|c|}{$\begin{array}{l}\text { Empirical data } \\
\text { Empirisjki podaci }\end{array}$} \\
\hline $\begin{array}{c}\text { SI } \\
\text { Indeks } \\
\text { staništa }\end{array}$ & Korf & Korsun & $\begin{array}{c}\text { CHR } \\
\text { Richards }\end{array}$ & M & $\begin{array}{l}\text { Min- } \\
- \text { Max }\end{array}$ & $S_{x}$ & SD \\
\hline \multicolumn{8}{|c|}{ (Years) } \\
\hline \multicolumn{8}{|c|}{ ŽA } \\
\hline $\mathrm{SI}_{32}$ & 26 & 27 & 27 & 27 & $24-31$ & 0.86 & 2.7 \\
\hline $\mathrm{SI}_{28}$ & 29 & 29 & 31 & 32 & $28-36$ & 0.85 & 2.8 \\
\hline $\mathrm{SI}_{24}$ & 32 & 31 & 36 & 37 & $33-42$ & 0.87 & 3.0 \\
\hline $\mathrm{SI}_{20}$ & 37 & 35 & 41 & 42 & $37-46$ & 1.02 & 3.2 \\
\hline $\mathrm{SI}_{16}$ & 43 & 39 & 47 & 48 & $41-57$ & 1.65 & 5.2 \\
\hline \multicolumn{8}{|c|}{$\mathrm{RU}$} \\
\hline $\mathrm{SI}_{32}$ & 22 & 23 & 22 & 22 & $20-26$ & 0.51 & 1.7 \\
\hline $\mathrm{SI}_{28}$ & 24 & 31 & 26 & 27 & $24-33$ & 0.82 & 2.7 \\
\hline $\mathrm{SI}_{24}$ & 27 & 37 & 31 & 32 & $29-37$ & 0.69 & 2.4 \\
\hline $\mathrm{SI}_{20}$ & 32 & 42 & 37 & 38 & $35-44$ & 0.83 & 2.8 \\
\hline $\mathrm{SI}_{16}$ & 38 & 47 & 46 & 45 & $40-53$ & 1.20 & 3.8 \\
\hline
\end{tabular}



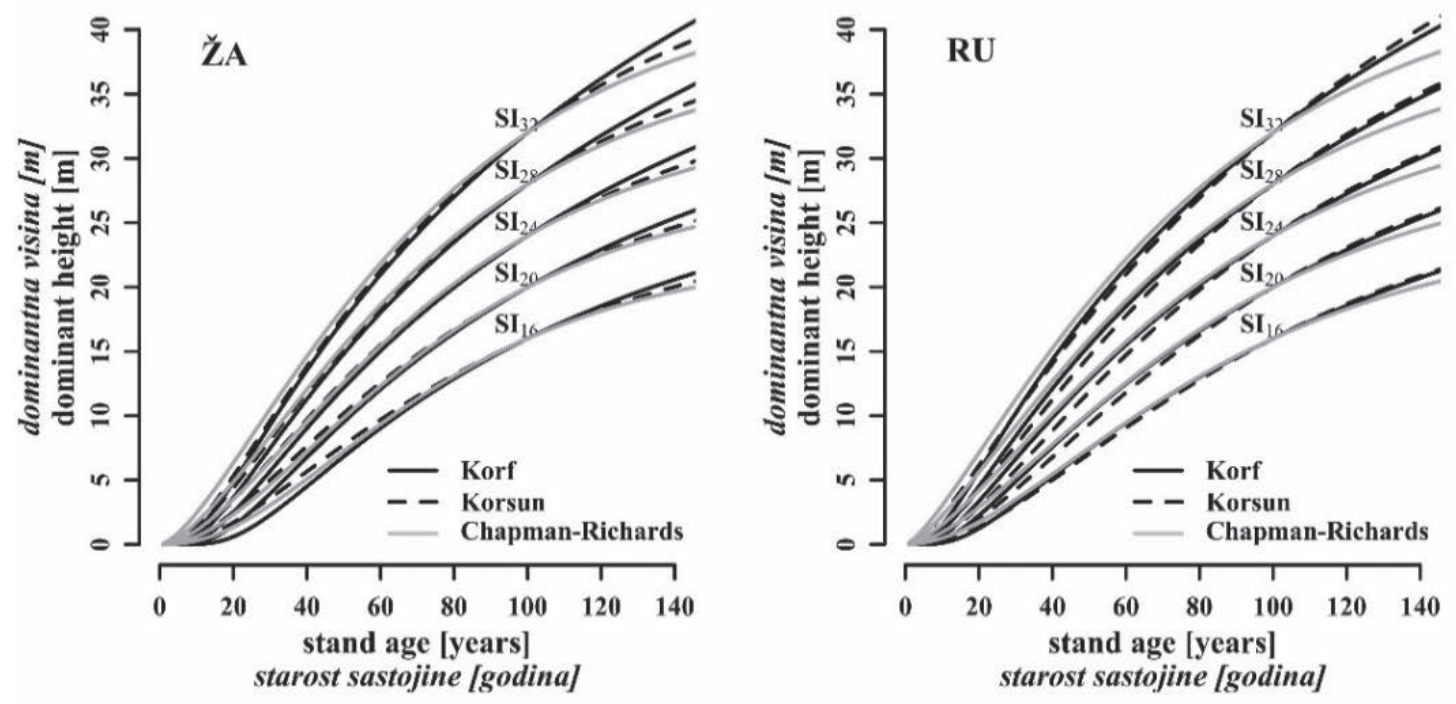

Figure 2. The polymorphic site index curves for the ŽA and RU regions obtained by applying the Korf, Korsun and Chapman-Richards growth functions.

Slika 2. Polimorfne krivulje indeksa staništa za ŽA i RU područja istraživanja, dobivene primjenom Korfove, Korsunove i Chapman-Richardsove funkcije rasta.

Table 5. Results of PRESS and RSS statistics for each site class (SC). Tablica 5. Rezultati PRESS i RSS statistike za svaku klasu staništa (SC)

\begin{tabular}{ccccccc}
\multicolumn{5}{c}{ Chapman-Richards } & \multicolumn{2}{c}{ Korsun } \\
SC & PRESS & RSS & PRESS & RSS & PRESS & RSS \\
& \multicolumn{5}{c}{ ŽA } \\
I & 217.02 & 192.53 & 183.06 & 162.60 & 179.36 & 159.63 \\
II & 130.77 & 119.33 & 139.37 & 127.06 & 153.40 & 139.09 \\
III & 102.99 & 87.60 & 125.20 & 105.32 & 165.14 & 139.55 \\
IV & 157.53 & 140.00 & 161.60 & 144.89 & 128.96 & 115.33 \\
V & 189.69 & 175.94 & 112.65 & 104.72 & 195.95 & 179.45 \\
SC & \multicolumn{5}{c}{ RU } \\
I & 447.54 & 401.84 & 342.18 & 311.19 & 501.65 & 440.00 \\
II & 382.34 & 346.60 & 316.16 & 282.40 & 338.36 & 301.86 \\
III & 294.41 & 261.38 & 353.56 & 301.85 & 287.34 & 247.66 \\
IV & 194.09 & 172.29 & 203.13 & 186.38 & 187.67 & 170.20 \\
V & 73.50 & 64.94 & 100.71 & 89.94 & 92.75 & 82.92
\end{tabular}

monly used three-parameter function in forest growth studies (Pretzsch 2001). Given its flexibility and suitability for describing various height growth patterns, many researches (Mamo and Sterba 2006, Batho and García 2014, Pyo 2017 etc.) have tested and employed only this growth function to develop site index curves. The results obtained in our study confirmed that the CHR model performed best, both concerning the significance and prediction accuracy of the model parameters and the biological justification of the models.

Regarding the accuracy of the model parameters of the mean height growth curve (guide curve) for each site class, it is first evident that although the values of RSE for the CHR model are slightly higher than for the others, all the parameters of the CHR model are more significant compared to the Korsun and the Korf models. Nonetheless, the Korf model produces unrealistic estimates of the parameters. Namely, the estimated value for the asymptote parameter of the Korf model (137 m - ŽA and $236 \mathrm{~m}$ - RU) for the first site class was extremely large. Conversely, a more realistic prediction of the asymptote parameters $(\approx 44 \mathrm{~m})$ was detected for the model of CHR, taking into account that the maximum beech tree heights recorded in the studied regions were about $40 \mathrm{~m}$. To be more precise, by applying the Korf (for both regions) and the Korsun (for RU) models, the calculated tree height values at the age of 150 were overestimated, indicating values over $40 \mathrm{~m}$ at site class I, which do not correspond to the values in reality. On the other hand, the CHR model, in both research sites, shows a height below $40 \mathrm{~m}$ at the age of 150 at the same site class (Figure 2).

Another criterion for the selection of the appropriate model to be used in our study was the residual statistics of the tested height growth curves (guide curves) for each site class in relation to their homogeneity. According to the obtained arithmetic mean of residuals (close to zero), the standard deviation values (within a value limit between $-2 \mathrm{~m}$ and 2 $\mathrm{m}$ corresponding to the width of site class of $4 \mathrm{~m}$ ) and the variation range of standard deviation, skewness and kurtosis coefficients (the smallest for the CHR model) for all five site classes, it can be concluded that the distribution of residuals for the CHR model showed the smallest deviations from normality, while the remaining two models expressed a degree of heteroscedasticity in some site classes.

The established site index curves point to some more and less important differences in beech height growth between regions (Figure 3). These disparities are primarily reflected in the attained tree height values at a certain age and in the 

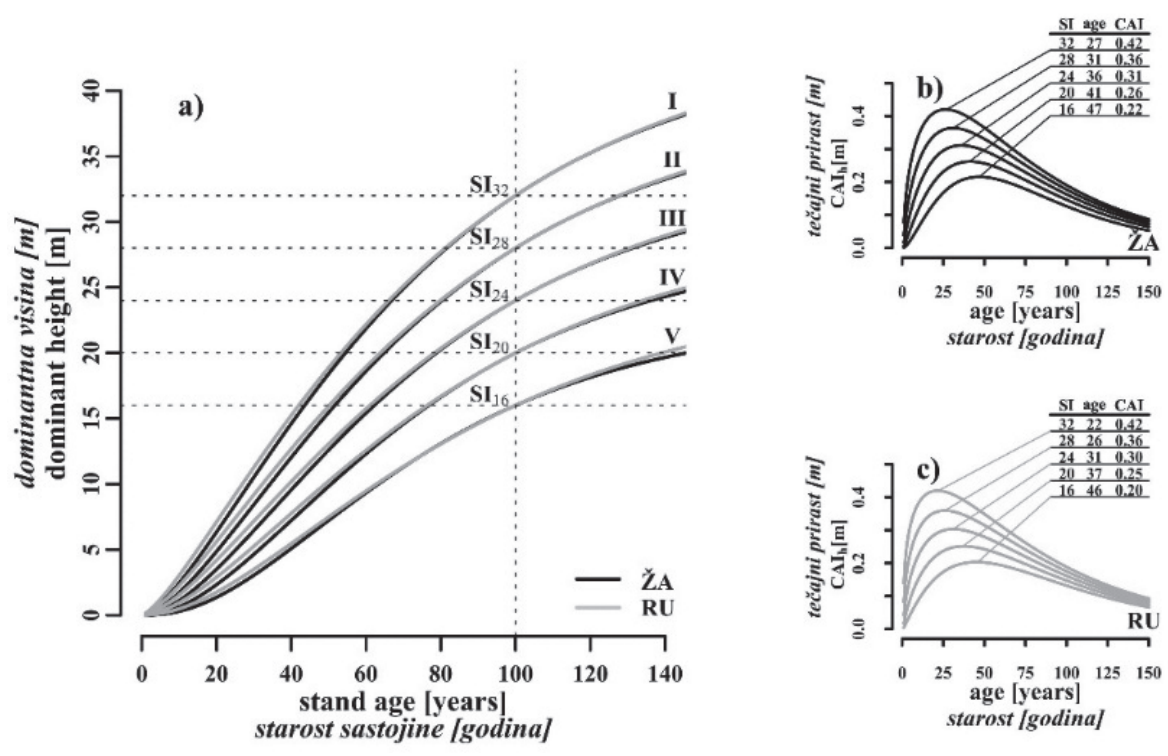

Figure 3. The site index curves constructed with the Chapman-Richards growth function (a), the corresponding curves of current annual increment of tree height (CAlh) for the ŽA (b) and RU (c) research sites. Black lines denote ŽA research site, grey lines denote RU research site.

Slika 3. Krivulje indeksa staništa konstruirane funkcijom Chapman-Richards-a (a), odgovarajuće krivulje godišnjeg tečajnog visinskog prirasta (CAlh) za područja istraživanja ŽA (b) i RU (c). Crne linije označavaju područje istraživanja ŽA, a sive područje istraživanja RU.

ages of the $\mathrm{CAI}_{\mathrm{h}}$ culmination. The differences are even greater in younger stands (more intensive height growth of RU beech compared to this from $\check{Z} A$ ), while they decrease gradually with increasing age and the heights of dominant trees from the RU and Ža become almost equalized in the later stages of growth.

Another desirable criterion for the site index model evaluation could be its "behaviour" in terms of the similarity between the results obtained by the model application and the empirical results, in this case with the empirical data of culmination ages and values of maximal $\mathrm{CAI}_{\mathrm{h}}$ per site class. The obtained results suggest that the site index curves obtained by the CHR function were best fitted into the data obtained by the stem analysis procedure. The models of Korf and Korsun produced relatively accurate results for the best two site classes, but generated unrealistic estimates for the site classes of the lower production capacitates. Therefore, it can be concluded that the CHR model also proved to be the best according to this biological criterion. Bearing in mind all of the above-mentioned, although verification statistics showed that none of the models was completely satisfactory, the CHR function was finally selected for the construction of polymorphic site index curves.

The mentioned biological criterion is very important because site index models may serve as a useful indicator in the quantification of the beginning and the cycle/frequency of thinning. Taking into account that cleaning felling of young stands is not generally performed, the silviculture of beech on sites of high productivity in Serbia traditionally promotes the execution of the first thinning as early as pos- sible, usually in the third decade (Stojanović and Krstić 2005), i.e. at the time of the $\mathrm{CAI}_{\mathrm{h}}$ culmination (Stajić 2010). The execution of the first thinning in the phase of high increment can be considered a favourable framework for achieving the biological and production optimum in beech stands (Matić et al. 2003, Bobinac 2004) and could be commonly considered more important than frequent intervention (Assman 1970). Additionally, on sites with higher SI values (sites with more vigorous growth) thinning cycle/ frequency will be more intensive than on sites with lower SI values, i.e. sites less vigorous growth (Pretzsch 2009). Therefore, the height growth of dominant trees contains two valuable components, the knowledge of which is of great importance for the planning of silvicultural activities: (1) growth of species depending on age and (2) the relationship of tree species to site conditions.

Regarding the values of the $\mathrm{CAI}_{\mathrm{h}}$ at the culmination age no significant differences were identified among the models (Figure 4). According to this model, the $\mathrm{CAI}_{\mathrm{h}}$ has approximately the same value for each site index in both areas. Namely, the value of the $\mathrm{CAI}_{\mathrm{h}}$ at the culmination age ranges from $0.42 \mathrm{~m}\left(\mathrm{SI}_{32}\right)$ to $0.20 \mathrm{~m}\left(\mathrm{SI}_{16}\right)$ for RU and from $0.42 \mathrm{~m}$ $\left(\mathrm{SI}_{32}\right)$ to $0.22 \mathrm{~m}\left(\mathrm{SI}_{16}\right)$ for $\check{\mathrm{Z}} \mathrm{A}$.

The modelled data of the $\mathrm{CAI}_{\mathrm{h}}$ culmination age per site class indicated that beech in the area of RU and ŽA (Table 4), for a given site class, reached the $\mathrm{CAI}_{\mathrm{h}}$ culmination age later than in Austria, where revealed at the age of 12, 13, 15, 17, and 21 (Kinderman 2004). To compare site index curves of the RU and ŽA with site index curves (site class II, III and IV) from Croatia (Špiranec 1975), based on the Loray's 


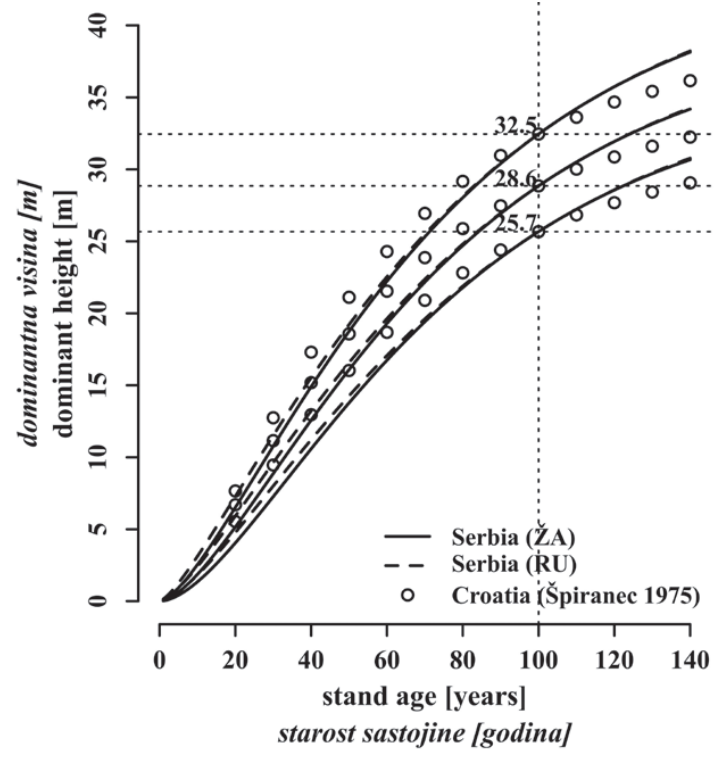

Figure 4. Comparison of the site index curves from the ŽA and RU regions and the height growth beech data from Croatia (Špiranec 1975). Slika 4. Usporedba krivulja indeksa staništa iz regija RU i ŽA i podataka 0 rastu visina bukve iz Hrvatske (Špiranec 1975).

mean height $\left(\mathrm{h}_{\mathrm{L}}\right)$, some corrections had to be made. For this purpose, we transformed the Špiranec's Loray's mean height data to the dominant height data $(\mathrm{H})$ according to the correction factor $\mathrm{H} / \mathrm{h}_{\mathrm{L}}$ derived from the yield tables from Austria (Eckmüllner 2011).

The culmination age of the $\mathrm{CAI}_{\mathrm{h}}$ from Croatia yield tables is close to the age of 20 years for all site classes, which is earlier than the $\mathrm{CAI}_{\mathrm{h}}$ culmination age for the RU and $\mathrm{Z} A$. Compared to Serbia, the results highlight a tendency of faster (under the age of 100) and slower (beyond this age) beech height growth in Croatia (Figure 4). The research results of Lukić et al. (2003) also confirmed that the height growth of beech in undisturbed stand conditions in Croatia can be relatively fast, with a large initial increment. Based on the analyzed 30 beech trees, these authors determined a much earlier culmination of the $\mathrm{CAI}_{\mathrm{h}}$ (at the age of 17, in average).

The culmination ages of the $\mathrm{CAI}_{\mathrm{h}}$ determined here are in accordance with the time frames defined in the beech growth research in Slovenia (Kadunc 2003) and Serbia (Stajić 2010). Namely, the mentioned authors defined that the $\mathrm{CAI}_{\mathrm{h}}$ of beech trees culminated in the range of 24 to 39 years (according to a unique model based on all used trees at the age of 29) and at the age of 23 and 27 (at the sites of medium productivity), respectively.

As noted, site index studies have not been intensively performed in Serbia. Ratknić (1998) presented beech site indices for the area of western Serbia. According to these results, the culmination of the current height increment on poor sites occurs earlier compared to more productive sites that can be considered inadequate according to the presentday knowledge. As mentioned earlier, it is well known that the better the site, the earlier the current height increment in even-aged stands culminates and the amount at the age of culmination is greater. By summarizing the available information about the Ratknićs method of site index construction provided, Stajić et al. (2016) concluded that it remains unclear whether the author has developed anamorphic or polymorphic site index curves.

Finally, the obtained site index curves should be primarily used to evaluate the production potential of beech on medium and low productive sites in our country. Further research of beech site productivity in Serbia needs to be performed for the most productive sites and in the direction of applying some of the base-age invariant modelling approaches, such as the algebraic difference approach - ADA (Bailey and Clutter 1974) and the generalised algebraic difference approach - GADA (Cieszewski and Bailey 2000).

\section{REFERENCES \\ LITERATURA}

- Assmann, E. 1970: The Principles of Forest Yield Study. Pergamon Press, 506 str.

- Bailey, R., J. Clutter, 1974: Base-age invariant Polymorphic site curves. Forest Science 20: 155-159

- Batho, A., O. García, 2014: A site index model for lodgepole pine in British Columbia. Forest Science Vol. 60 (5): 982-987

- Bobinac, M. 2004: Efekti selektivne prorede na prirast stabala i sastojina bukve na Južnom Kučaju. Glasnik Šumarskog fakulteta, 90: 65-78, Beograd

- Bontemps, J. D., O. Bouriaud, 2014: Predictive approaches to forest site productivity: recent trends, challenges and future perspectives. Forestry 87: 109-128

- Cieszewski, C. J., R L. Bailey, 2000: Generalized Algebraic Difference Approach: Theory based derivation of dynamic site equations with polymorphism and variable asymptotes. Forest Science Vol. 46 (1): 116-126

- Clutter J. L., J. C. Fortson, L.V. Pienaar, G. H. Brister, R. L. Bailey, 1983: Timber management - A quantitative approach, John Wiley \&Sons, 333 str., New York

- Davis, L. S., N. N. Johnson, 1987: Forest Management. $3^{\text {rd }}$ Ed., McGraw-Hill, 790 str., New York

- Eckmüllner, O. 2011: ErtragstafelBucheTirol.13p., https://www. tirol.gv.at/fileadmin/themen/umwelt/wald/waldwirtschaft/ downloads/buche_Tirol_broschuere.pdf

- García, O. 2011: Dynamical implications of the variability representation in site-index modelling. Eur J Forest Res, 130: 671-675

- Halaj, J. 1978: Výškový rast a štruktúra porastov.. Veda, vydavatel'stvo Slovenskej akadémie vied, 283 str., Bratislava.

- Kadunc, A., 2003: Vloga gorskog javora (Acer pseudoplatanus L.) v gozdnih ekosistemih. Disertacija, Biotehniška fakulteta, Ljubljana.

- Kindermann, G. 2004: Wachstumssimulation in Mischbeständen. Dissertation, Universität für Bodenkultur, Wien, 146 str. 
- Kramer, H. 1988: Waldwachstumslehre. Paul Parey., 374 str., Hamburg-Berlin

- Lukić, N 1988: Udaljenost dominantnih stabala obične bukve (Fagus sylvatica L.) u jednodobnim sastojinama. Šumarski list, 3-4: 115-124, Zagreb

- Lukić, N., Ž. Galić, M. Božić, 2003: Rast i prirast obične bukve. U: S. Matić. (Ur.). Obična bukva u Hrvatskoj. Akademija šumarskih znanosti, 449-463, Zagreb

- Matić, S., I. Anić, M. Oršanić, 2003: Uzgojni postupci u bukovim šumama. U: S. Matić. (Ur.). Obična bukva u Hrvatskoj. Akademija šumarskih znanosti, 340-392, Zagreb

- Mamo, N. H. Sterba, 2006: Site index functions for Cupressus lusitanica at Munesa Shashemene, Ethiopia. Forest Ecol. Manag. 237: 429-435

- Monserud, R. A. 1984: Height Growth and Site Index Curves for Inland Douglas-fir based on Stem Analysis data and Forest habitat Type. Forest Science Vol. 30 (4): 943-965

- Nanang, D. M., T. K. Nunifu, 1999: Selecting a functional form for anamorphic site index curve estimation, Forest Ecol. and Manag., 118: 211-221

- Newberry, J. D. 1991: A Note on Carmean's Estimate of Height from Stem Analysis Data. Forest Science Vol. 37 (1) 368-369

- Palahi, M., M. Tome, T. Pukkala, A. Trasobares, G. Montero, 2004: Site index model for Pinus sylvestris in north-east Spain. Forest Ecol. Manag., 187: 35-47

- Pyo, J. 2017: Developing the site index equation using a generalized algebraic difference approach for Pinus densiflora in central region, Korea. Forest Science and Technology 13 (2): 87-91

- Pretzsch, H. 2001: Modellierung des Waldwachstums. Parey Buchverlag, 341 str., Berlin,

- Pretzsch, H. 2009: Forest Dynamics, Growth and Yield. Springer-Verlag, , 664 str., Berlin Heidelberg

- Ratknić, M. 1998: Razvojno-roizvodne karakteristike bukovih sastojina u zavisnosti od ekoloških vrednosti staništa u jugozapadnoj Srbiji. Posebno izdanje, Institut za šumarstvo, 174 str., Beograd

- R Development Core Team 2008: R: A language and environment for statistical computing. R Foundation for Statistical Computing, Vienna, Austria. http://cran.r-project.org/

- Schmidt, A. 1969: Der Verlauf des Höhenwachstums von Kiefern auf einigen Standorten der Oberpfalz Forstwissenschaftliche Centralblatt 88: 33-40

- Skovsgaard, J. P., J. K. Vanclay, 2008: Forest site productivity: a review of the evolution of dendrometric concepts for even-aged stands. Forestry 81:13-31
- Sloboda, B. 1971: Zur Darstellung von Wachstumasprozessen mit Hilfe von diferential Gleichungen erster Ordnung. Mitt. d. FVA 32, 109 str.

- Socha J, N. C Coops, W. Ochal, 2016:. Assessment of age bias in site index equations. iForest 9: 402-408.

- Stajić, B., 2010: Karakteristike strukture i rasta stabala u mešovotim sastojinama bukve i plemenitih lišćara. Disertacija, Šumarski fakultet, Beograd.

- Stajić, B., Ž. Janjatović, P. Aleksić, Z. Baković, M. Kazimirović, N. Milojković, 2016: Anamorphic site index curves for Moesian beech (Fagus $\times$ taurica Popl.) in the Region of Žagubica, Eastern Serbia., Croatia, Šumarski list 5-6: 251-258, Zagreb

- Stamenković, V., M. Vučković, 1988: Prirast i proizvodnost šumskih stabala i sastojina. Univerzitet u Beogradu - Šumarski fakultet, 368 str., Beograd

- Stojanović, Lj., M. Krstić, 2005: Prirodno obnavljanje, podizanje i nega bukovih šuma, U: Lj. Stojanović (Ur.) Bukva u Srbiji. Udruženje šumarskih inženjera i tehničara Republike Srbije, Univerzitet u Beogradu - Šumarski fakultet, 352-364, Beograd

- Špiranec, M. 1975: Prirasno-prihodne tablice. Šumarski institut "Jastrebarsko", Radovi 25, 110 str., Zagreb

- Usta, A., M. Yilmaz, S. Yilmaz, J. O. Kocamanoğlu, E. Genç, I. Turna, 2019: The effects of thinning intensity on the growth of Oriental beech (Fagus orientalis Lipsky) plantations in Trabzon, NE Turkey. Šumarski list, 5-6: 231-240, Zagreb

- Vanclay, J. K., N B. Henry, 1988: Assessing site productivity of indigenous cypress pine forest in southern Queensland. Commonwealth Forest Review 67: 53-64.

- Vučković, M., 1989: Razvojno proizvodne karakteristike crnog bora u veštački podignutim sastojinama na Južnom kučaju i Goču. Disertacija. Beograd.

- Vučković, M, B. Stajić, 2003: Ocena stanja sastojina bukve na bazi osnovnih elemenata rasta. Glasnik Šumarskog fakulteta Univerziteta u Beogradu 87, 95-102, Beograd.

- Vučković, M., B. Stajić, 2005: Razvojno-proizvodne karakteristike bukve, U: Lj. Stojanović (Ur.), Bukva u Srbiji. Udruženje šumarskih inženjera i tehničara Republike Srbije, Univerzitet u Beogradu - Šumarski fakultet, 352-364, Beograd.

- Zelić, J. 2005: Prilog modeliranju normaliteta regularnih srednjodobnih bukovih sastojina (EGT-II-D-10). Šumarski list 1-2, 51-62, Zagreb

- Zlatanov, T., I. Velichkov, G. Hinkov, M. Georgieva, O. Eggertsson, S. Hreidarsson, M. Zlatanova, G. Georgiev, 2012: Site index curves for European chestnut (Castanea sativa Mill.) in Belasitsa mountain, Šumarski list, Vol. 136 (3-4): 153-159, Zagreb.

\section{SAŽETAK}

Moderno uzgajanje šuma, predviđanje rasta i prirasta, uređivanje šuma i donošenje odluka na različitim razinama, zahtijevaju pouzdane pokazatelje proizvodnosti staništa. Najvažniji pokazatelj potencijalne proizvodnosti šumskih staništa je dominantna visina sastojine u referentnoj dobi - stanišni indeks.

Usprkos velikom značenju evaluacije proizvodnog potencijala staništa za gospodarenje šumama, istraživanja proizvodnosti staništa u vidu stanišnih indeksa nisu intenzivno provođena u Srbiji, ali i u cijeloj regiji zemalja s prostora bivše države Jugoslavije (s izuzetkom Slovenije). Stoga je cilj istraživanja bio (1) modeliranje odnosa visine i starosti dominantnih stabala bukve i (2) konstrukcija polimorfnih krivulja stanišnih indeksa za bukvu u središnjoj i istočnoj Srbiji te (3) usporedba dobivenih rezultata iz Srbije s rezultatima o visinskom rastu i prirastu bukve iz zemalja u neposrednoj blizini. 
Istraživanje je provedeno u bukovim jednodobnim sastojinama u području Žagubice - ŽA, u istočnoj Srbiji (oko 15.000 ha ukupne površine pod šumom) i planine Rudnik - RU, u središnjoj Srbiji (oko 7.000 ha ukupne površine pod šumom). Uzorak od 53 (ŽA) i 53 (RU) dominantnih stabala bukve korišten je za dobivanje odgovarajućih podataka o visini stabala u različitim dobima. Stabla su odabrana tako da pokrivaju širok raspon dobi i uvjeta staništa unutar područja istraživanih kompleksa bukovih šuma. Za utvrđivanje polimorfnih krivulja staništa testirane su funkcije Korfa, Korsuna i Chapman-Richardsa (CHR), čiji su parametri utvrđeni metodom predviđanja vrijednosti parametara.

Rezultati dobiveni u našoj studiji ukazali su da se CHR model pokazao najboljim i kada su u pitanju značajnost i preciznost predviđanja parametara modela, ali i biološke značajke modela koje se odnose na uklapanje modela u mjerene podatke o visinskom rastu i prirastu bukve. Također, raspodjela reziduala kod CHR modela pokazala je najmanja odstupanja od normalne, dok su ostala dva modela imala određeni stupanj heteroscedastičnosti.

Drugi poželjan kriterij za ocjenu modela indeksa staništa može biti njegovo „ponašanje“ u pogledu sličnosti rezultata dobivenih primjenom modela i empirijskih rezultata, u ovome slučaju s empirijskim podacima o dobi kulminacije i maksimalnih vrijednosti tečajnog visinskog prirasta $\left(\mathrm{CAI}_{\mathrm{h}}\right)$ po klasi staništa. Dobiveni rezultati sugeriraju da su se krivulje indeksa staništa generirane funkcijom CHR najbolje uklopile u podatke dobivene postupkom analize stabla. Modeli Korf i Korsun dali su relativno točne rezultate za najbolje dvije klase staništa (bonitete), ali generirali su nerealne procjene za slabije produktivna staništa. Stoga se može zaključiti da se CHR model pokazao najboljim i prema ovom biološkom kriteriju. Modelirani podaci o dobi kulminacije $\mathrm{CAI}_{\mathrm{h}}$ pokazali su da bukva na području RU i ŽA dostiže dob kulminacije godišnjeg tečajnog visinskog prirasta $\left(\mathrm{CAI}_{\mathrm{h}}\right)$ kasnije nego u Austriji i Hrvatskoj, dok je slična dobi utvrđenoj u Sloveniji i Srbiji (sa drugog područja).

Dobivene krivulje indeksa staništa ponajprije se trebaju koristiti za procjenu proizvodnog potencijala bukve na srednjim i nisko produktivnim staništima u Srbiji. Daljnje istraživanje u Srbiji treba provesti na najproizvodnijim staništima i u smjeru primjene nekih "od bazične dobi nezavisnih" pristupa, kao što su algebrični diferencijalni pristup - ADA i generalizirani algebrični diferencijalni pristup - GADA. Determinirane polimorfne krivulje stanišnih indeksa bukve su vrlo korisne u određivanju odgovarajućih uzgojnih tretmana, općoj klasifikaciji staništa s obzirom na njihovu kvalitetu i za primjenu načela potrajnog gospodarenja šumama. 